\title{
PENGARUH PERTUMBUHAN PENDUDUK TERHADAP PERTUMBUHAN EKONOMI
}

\author{
Azulaidin, SE,M.Si \\ Universitas Amir Hamzah \\ azul.aidin@gmail.com
}

\begin{abstract}
Abstrak
Untuk mengetahui pengelolaan pertumbuhan ekonomi dibutuhkan pengetahuan tentang analisis perkembangan beberapa indikator makro ekonomi seperti pengangguran, tingkat Inflasi, dan pertumbuhan penduduk. Dimana Peningkatan pengangguran, tingkat Inflasi dan pertumbuhan penduduk ini dapat menentukan tingkat pertumbuhan ekonomi suatu wilayah. pertumbuhan penduduk dan Inflasi tidak berpengaruh terhadap pertumbuhan ekonomi karena pertumbuhan penduduk dengan kapasitas baik akan meningkatkan jumlah produksi dan penyerapan akan hasil produksi juga akan meningkat seiring banyaknya jumlah penduduk yang ada. Sehingga perputaran ekonomi akan berjalan dengan lancar dengan tujuan pertumbuhan ekonomi menjadi tidak terhambat. Pertumbuhan penduduk adalah sebuah proses keseimbangan yang dinamis antara komponen kependudukan yang dapat menambah dan mengurangi jumlah penduduk. Pertumbuhan Ekonomi terutama pertumbuhan ekonomi wilayah adalah pertambahan pendapatan masyarakat secara keseluruhan yang terjadi di wilayah tersebut, yaitu kenaikan seluruh nilai tambah (added value) yang terjadi.
\end{abstract}

\section{Keyword : Pertumbuhan Penduduk, Pertumbuhan Ekonomi.}

\section{PENDAHULUAN}

Pertumbuhan penduduk yang tinggi dianggap oleh sebagian ahli ekonomi merupakan penghambat pembangunan. Mulyadi menyatakan bahwa tingginya angka pertumbuhan penduduk yang terjadi di negara sedang berkembang seperti Indonesia dapat menghambat proses pembangunan. Malthus dalam Deliarnov mengamati manusia berkembang jauh lebih cepat dibandingkan dengan produksi hasil-hasil pertanian untuk memenuhi kebutuhan manusia. Manusia berkembang 
sesuai dengan deret ukur. Sementara itu, pertumbuhan produksi makanan hanya meningkat sesuai dengan deret hitung. Karena perkembangan jumlah manusia jauh lebih cepat dibandingkan dengan pertumbuhan produksi hasil-hasil pertanian. Berdasarkan teori Lincolin Arsyad dan Mulyadi dapat disimpulkan bawasannya tingkat pengangguran, inflasi dan pertumbuhan penduduk memiliki hubungan terhadap pertumbuhan ekonomi. Dimana ketiganya merupakan indikator penting yang harus dibahas. Jumlah pengangguran disuatu wilayah akan memperlihatkan seberapa tingginya produktifitas yang dimiliki oleh penduduk disuatu wilayah kemudian inflasi yang merupakan kenaikan harga-harga barang, memperlihatkan bagaimana proporsi untuk bahan baku produksi suatu usaha maupun hal-hal lain yang terkait. Dan pertumbuhan penduduk akan memperlihatkan bagaimana keadaan penduduk suatu wilayah. Pertumbuhan Ekonomi yang merupakan pertambahan pendapatan masyarakat secara keseluruhan yang terjadi di wilayah tersebut, yaitu kenaikan seluruh nilai tambah yang terjadi. Hal ini merupakan salah satu indikator yang amat penting dalam menilai kinerja suatu perekonomian, terutama untuk melakukan analisis tentang hasil pembangunan ekonomi yang telah dilaksanakan suatu negara atau suatu daerah. Kenaikan seluruh nilai tambah atau pertumbuhan ekonomi ini akan dipangaruhi berbagai hal yang salah satunya adalah faktor-faktor didalam pertumbuhan ekonomi seperti pengangguran, inflasi dan pertumbuhan penduduk. Ini artinya, baik pengangguran, inflasi dan jumlah penduduk dimungkinkan memiliki pengaruh yang signifikan terhadap pertumbuhan ekonomi.

\section{KAJIAN PUSTAKA}

Orang yang pertama membahas pertumbuhan ekonomi secara sistematis adalah Adam Smith. Dalam pemikirannya, Smith mengkritik pandangan kaum merkantilis. Menurut Smith, kepemilikan atas emas dan perak oleh suatu negara bukanlah ukuran suatu kekayaan nasional, karena kekayaan nasional haruslah bersumber pada hasil kerja suatu negara. Kekayaan nasional dapat dibentuk oleh dua hal yaitu Keterampilan dan penggunaan tenaga kerja secara efisien kemudian Perimbangan yang tepat antara tenaga kerja produktif dan nonproduktif. Untuk meningkatkan pembangunan nasional, maka harus didukung dengan pembangunan daerah yang dilaksanakan secara tepat. Laju pertumbuhan ekonomi daerah biasanya digunakan untuk menilai seberapa jauh keberhasilan pembangunan daerah dalam periode waktu tertentu. Pertumbuhan ekonomi daerah tersebut dapat ditunjukkan oleh kenaikan GDP atau PDRB.

Pembangunan ekonomi daerah adalah suatu proses dimana pemerintah daerah dan masyarakatnya mengelola sumber-sumber daya yang ada dan membentuk suatu pola kemitraan antara pemerintah daerah dan swasta untuk menciptakan lapangan kerja baru dan merangsang perkembangan kegiatan ekonomi dalam wilayah tersebut. Menurut Smith, pertumbuhan penduduk dinilai mampu mendorong pertumbuhan ekonomi. bertambahnya penduduk akan memperluas pasar, dan 
perluasan pasar akan mempertinggi tingkat spesialisasi dalam perekonomian. Karena adanya spesialisasi akan meningkatkan produktifitas tenaga kerja dan mendorong perkembangan teknologi. Pertumbuhan penduduk adalah sebuah proses keseimbangan yang dinamis antara komponen kependudukan yang dapat menambah dan mengurangi jumlah penduduk. Yang menjadi permasalahan dalam pertumbuhan penduduk adalah pertumbuhan penduduk yang cukup tinggi ini dapat menimbulkan berbagai masalah dan hambatan dalam pembangunan ekonomi. Dengan keadaan yang demikian di mungkinkan pertumbuhan penduduk akan menjadi penghambat pertumbuhan ekonomi di suatu wilayah jika dalam penanganannya tidak bisa dilakukan dengan efektif.

\section{Jenis Penelitian}

\section{METODE PENELITIAN}

Dalam penelitan ini penulis menggunakan metode pendekatan secara kuantitatif. Metode kuantitatif adalah metode penelitian yang dapat diartikan sebagai metode penelitan yang berlandaskan pada filsafat positivisme, digunakan untuk meneliti pada populasi atau sampel tertentu, pengumpulan data menggunakan instrument penelitian, analisis data bersifat kuantitatif dengan tujuan untuk menguji hipotesis yang telah ditetapkan.

\section{Sifat Penelitian}

Dilihat dari sifatnya penelitian ini bersifat Asosiatif (Hubungan), yaitu suatu metode penelitian yang bertujuan untuk mengetahui hubungan antara dua variabel atau lebih, dimana penelitian ini bertujuan untuk mengetahui hubungan pengaruh antara variabel bebas yaitu pengangguran, inflasi dan pertumbuhan penduduk terhadap variabel terikat yaitu pertumbuhan ekonomi. Dengan penelitian ini, maka akan dapat dibangun teori yang dapat berfungsi untuk menjelaskan, meramalkan dan mengontrol suatu gejala.

\section{Teknik Pengumpulan Data}

Dalam teknik pengumpulan data, Untuk mengumpulkan data dan imformasi penelitian ini menggunakan metode dokumentasi. Metode Dokumentasi adalah pengumpulan data dengan jalan melihat, membaca, mempelajari, kemudian mencatat data yang sudah ada hubungannya dengan objek penelitian. Metode ini dilakukan dengan mengambil dokumentasi atau data yang mendukung penelitian.

\section{KESIMPULAN}

\section{Kesimpulan}

Berdasarkan pada penelitian yang telah dilakukan oleh peneliti, maka diambilah kesimpulan sebagai berikut:

1. Selain itu pertumbuhan penduduk yang pesat akan mengakibatkan 
melimpahnya tenaga kerja kemudian kebutuhan bagi penduduk juga ikut meningkat seiring bertambahnya jumlah penduduk, pemerintah harus mampu memberdayakan sumberdaya manusia yang tinggi karena hal ini bisa menjadi potensi yang baik apa bila pengelolaannya dilakukan secara efektif dan berkelanjutan.

2. Kepemilikan emas dan perak disuatu negara bukanlah ukuran dari kekayaan nasional atau tingkat ekonomi yang bagus. karena kekayaan nasional dan tingkat ekonomi yang bagus bersumber pada keterampilan dan penggunaan tenaga kerja secara efisien dan perimbangan antara tenaga kerja produktif dan non produktif.

\section{Saran}

1. Dengan adanya hasil penelitian ini diharapkan adanya sebuah upaya yang dilakukan dalam menangani permasalahan pengangguran melalui kebijakan pemberdayaan penduduk dan perluasan lapangan kerja dengan mendukung UMKM (usaha mikro kecil menengah).

2. Pengoptimlan kinerja tim pengendali Inflasi Provinsi (TPIP) untuk menjaga kesetabilan ekonomi melalui inflasi daerah dengan harapan perekonomian di provinsi semaikin bergairah dan pertumbuhan ekonomi yang terus meningkat.

\section{REFERENCES}

Prathama Raharja Dan Mandala Manurug, Edisi Ke 3, Pengantar Ilmu Ekonomi, Jakarta: Fakultas Ekonomi Indonesia,2008

Robinson Tarigan, EKONOMI REGIONAL Edisi Revisi, Jakarta: PT Bumi Aksara, 2014

Subandi, Konomi Pembangunan, Alfa Beta, Bandung, 2014

Sudono sukirno, Makro Ekonomi Moderen Jakarta: PT Raja Grafindo Persada, 2000

Sudjana, Metode Statistik,Bandung : PT. Tarsito 2009 Sugiono, Penelitian Administrative, Bandung :Alfa Beta, 2001 Sutrisno Hadi, Metode Reseach Yogyakarta: ANDI,2002

Usman, Husaini dan Setiadi, Pengantar Statistika,Jakarta: PT Bumi Aksara,2003

V. Wiratna Sujarweni, SPSS Untuk Penelitian, Yogyakarta : Pustaka Baru 2015 
Juripol, Volume 4 Nomor 1 Maret 2021 